\title{
Impact of Consumer Environmental Concern in the Post-corona Era on Purchase Intention of Environmentally Friendly Cosmetics with Awareness of Sustainability Management Activities from Cosmetics Companies as a Medium
}

Min-Hye Kim ${ }^{1}$, Seunghee Bae ${ }^{2 *}$

${ }^{1}$ Department of Cosmetics Engineering, Konkuk University, Seoul, Korea

${ }^{2}$ Research Institute for Molecular-Targeted Drugs, Department of Cosmetics Engineering, Konkuk University, Seoul, Korea

\author{
"Corresponding author: Seunghee \\ Bae, Research Institute for Molecular- \\ Targeted Drugs, Department of Cosmetics \\ Engineering, Konkuk University, 120 \\ Neungdong-ro, Gwangjin-gu, Seoul 05029, \\ Korea \\ Tel.: +82 24500463 \\ Fax: +8227378360 \\ Email: sbae@konkuk.ac.kr
}

Received April 9, 2021

Revised May 25, 2021

Accepted June 02, 2021

Published June 30, 2021

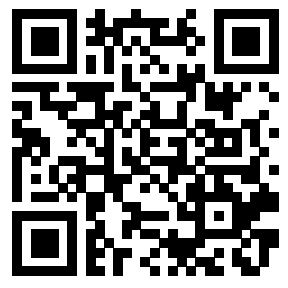

\begin{abstract}
Purpose: In this study, we aim to understand the structural correlation between consumer environmental concerns in the post-corona era and its impact on both purchase intention for environmentally friendly cosmetics and the perception of sustainability management activities practiced by cosmetics companies. Method: A survey was conducted from February 21 to 27, 2021, targeting adults who use cosmetics. Out of 371 samples, 334 valid samples were analyzed using the SPSS 18.0 program, and the reliability and validity were verified with Cronbach's $\alpha$. Results: It was found that environmental concerns from consumers had a significant influence on the intent to purchase environment-friendly cosmetics and on awareness of sustainability management activities implemented by cosmetic companies. Conversely, awareness of sustainability management activities significantly impacted the purchase intention for environment-friendly cosmetics. It was also discovered that perception of sustainability management activities played a huge mediating role in consumer environmental concern by influencing cosmetics purchase intention. Overall, environmental concern, awareness of sustainability management activities practiced by companies, and purchase intention grew parallel with the age of the group. The analysis showed that awareness of corporate sustainability management activities had an indirect effect in all age groups between 20 and 60 years old. Conclusion: Consumer environmental concerns in the postcorona era have impacted awareness of sustainability management activities by cosmetic companies while simultaneously affecting the purchasing of environmentfriendly cosmetics. Per this awareness, cosmetic companies should seek to implement a sustainability management stratagem that satisfies both, the company and consumers.
\end{abstract}

Keywords: Post-Corona, Environmental concern, Sustainability management, Environmental friendly cosmetics, Purchase intention

\section{Introduction}

\section{1. 연구의 필요성 및 목적}

코로나19 이후 다가올 새로운 일상 및 사회적·경제적 변화를 '포스 트 코로나(Post-Corona)'로 일컫는다. 2020년 미래학자 Friedman은 COVID-19로 세계는 이제 before Corona (BC)와 after Corona (AC)로
나뉠 것이라고 전망하였다. 특히 제조업의 변화가 가장 두드러질 것이 라고 하였다. 화장품 기업 역시 이러한 변화에 많은 영향을 받고 있으 며, 코로나19는 여성들의 화장에 관한 관심도나 트렌드를 변화시키고 있다. 스킨케어에 대한 관심은 높아진 반면 메이크업에 대한 전반적인 관심도 줄었다(Park \& Kim, 2021). 하지만 코로나19 (COVID-19)로 인해 생활에 제약이 따르는 악조건 속에서도 각종 소셜 미디어를 통 
해 자기 생활의 과시를 하고 싶어 하는 젊은 층과 나이보다 어려 보이 고자 하는 액티브 시니어가 폭발적으로 증가하였다(Lee et al, 2021). 뷰티 산업에서는 이러한 트렌드 변화를 인식하며 이를 극복하기 위한 제품개발 및 마케팅 대응 전략 수립이 필요한 시점이다(Park \& Kim, 2021). 이러한 변화와 함께 Koh \& Lee (2020)는 세계적으로 확산된 코로나19는 정치, 경제, 사회는 물론 우리의 소비생활에 영향을 미치 고 있으며, 현대 사회의 소비중심적 문화가 유해한 환경적 결과를 낳 을 수 있고, 인간의 생존과 삶의 질에 직접적인 영향을 미칠 수 있다는 것을 여실히 보여줌으로써 그 동안 자행된 인류의 무모한 개발과 환경 파괴에 경종을 울리는 계기가 되었다. 코로나 19 이후 사회적으로 환경 보호에 자연에 관한 관심이 높아진 만큼 지속 가능성에 관한 중요성이 강조되고 있으며, 이에 따라 지속가능한 제품에 대한 소비도 증가하고 있는 추세라고 하였다.

지속가능성이란 불확실한 미래는 물론 현재에도 환경과 사람 에 모두 최선의 혜택을 주는 것이다. 1987년의 브룬틀랜드 보고서 (Brundtland report)에서는 지속가능성이란 "미래 세대의 가능성을 제 약하는 바 없이, 현세대의 필요와 미래 세대의 필요가 조우하는 것" 이라고 지칭한 바 있다(Kim, 2012). 1987년 세계 환경개발위원회 (WCED)는 "미래 세대의 필요를 충족시킬 수 있는 능력을 손상시키지 않는 범위에서 현재 세대의 필요를 충족시키는 발전"이라고 지속가능 한 발전 개념을 소개하였다(Kang \& Jeong, 2014).

국제 사회는 이윤 극대화를 통해 양적 성장을 도모하는 전통적인 기 업 경영 방식이 인류의 삶의 질을 오히려 퇴보 시 킬 것이라는 전망을 내놓고 있다. 즉 과도한 개발로 인한 생태 환경의 훼손, 천연자원의 고 갈, 환경오염으로 인한 기후 변화와 자연재해 등이 급증하고 있는 실 정이다(Lee \& Kim, 2015). 기업의 환경적 책임은 시장 규모의 확대와 영업 전략의 글로벌화로 인하여 자연환경 훼손이 심각하게 발생하는 현대사회에서 자원고갈 및 생태계에 미치는 부정적 결과를 해결하는 보다 실천적, 규범적 경영전략이라 할 수 있다(Kang \& Jeong, 2014).

따라서 기업의 환경보전에 대한 책임은 기업의 사회적 책임의 하나 로서 비중이 커지고 있으며, 나아가 기업 경영의 패러다임을 환경 친 화적 경영에서 기업에 부여된 경제·환경·사회적 책임을 준수함으로 써 장기적으로 생존할 수 있는 토대를 마련하는 지속가능경영으로 바 뀌고 있다(Cho \& Han, 2017). 기업의 글로벌 경영환경의 불확실성 이 더욱 더 커지고 있는 상황에서 최우선 과제는 기업의 지속가능성 (corporate sustainability)이다. 따라서 대다수 경영자들은 기업의 지 속가능성 문제를 해결해야 한다는 압박감에 시달리고 있는 실정이다 (Lee et al, , 2020).

기업이 인간 삶에 긍정적 영향을 미치고 경제성장을 견인하는 중추 로 작용한다는 점을 인정하면서도, 기업의 경영환경 이면에 펼쳐지는 환경오염, 황금만능주의 같은 부정적인 효과의 대중적 이목에도 핵심 적인 이해관계자로 함께했다는 점은 부인할 수 없다(Kong \& Hong, 2020). 또한 환경보호에 관한 문제는 범 지구적으로 다루어지고 있 으며 우리나라 또한 환경보호에 관한 활동이 나날이 증가하고 있다.
2018년 7월부터 정부에서는 미세플라스틱이 함유된 화장품 판매를 금 지하였고, 매장에서 음용 시 플라스틱 사용을 제한하고 있으며, 지하 철이나 공공기관에서는 우산 비닐 커버 대신 우산 빗물 제거기를 설치 하였다. 일부 기업들은 친환경 소재를 사용하여, 재활용이 편리한 상 품을 선보이기도 하면서 환경 친화적인 기업 이미지 마케팅을 펼치고 있다(Park \& Nam, 2019). 이러한 추세로 급변하는 정치, 경제, 사회, 문화적 맥락 속에서 소비자의 요구는 다변화되고 있으며, 이들은 전통 적인 상품과 서비스의 공급주체를 뛰어넘는 기업활동을 주장하고 있 다(Kong \& Hong, 2020). 우리나라 뷰티 산업 또한 전 세계적인 수준 에서 화장품 강국으로 발전하면서 환경 부하를 증가시키고 있는 현실 이다. 다른 나라 뷰티 산업에서는 이미 환경 친화적 기업 이미지 구축 수준을 넘어서 환경보호에 직접적으로 기여할 수 있는 환경경영 기법 들이 실무 현장에서 활용되고 있는 추세이다(Jeung, 2020).

기업들은 고객과의 장기적인 관계를 유지하기 위해 브랜드 구축에 많은 노력을 기울이고 있는데 이를 효과적으로 수행하는 것 중 하나 가 친환경 혜택을 주는 활동이라고 인식하고 있다(Lee \& Lee. 2012). 위와 같은 실정에도 우리나라 뷰티 산업에 속한 기업들은 환경경영 을 시도하고 있는 기업들이 현저하게 적은 실정이다. 반면 국제적으로 는 대기업뿐만 아니라 중소기업도 사회적 책임 경영을 통해 내수 시장 에서의 경제적 성과를 확보하고, 수출 시장에서의 무역 장벽을 해결 할 요소가 될 것이라는 판단에 따라 지속가능보고서를 작성하고 있다 (Jeung, 2020).

국내 화장품 제조업종에 속한 기업들 (LG생활건강, 아모레퍼시픽, 유한킴벌리, 유니베라, 에프에스코리아, 엔베코팜 등)에서 지속가능성 보고서를 작성하고 있다(Jeung, 2020). 하지만 지속가능경영에 대한 소비자의 인식과 및 연구와 마케팅 성과에 대한 연구는 전무하다. 따 라서 본 연구에서는 포스트 코로나 시대의 소비자들의 환경의식을 바 탕으로 친환경 지속가능 경영 활동 인식과 친환경 화장품 구매의도의 상관관계를 확인하고자 한다. 이에 본 연구는 화장품 기업의 마케팅 기초자료로 제공할 수 있다는 점에서 의의가 있다.

\section{2. 연구문제}

본 연구에서는 포스트 코로나 시대의 소비자들의 환경의식이 화장 품 기업의 지속가능경영 활동 인식에 영향을 주는 구조적 관계를 파악 하고자 한다. 또한 소비자들의 환경의식이 친환경 화장품 구매의도에 영향을 주고, 화장품 기업의 지속가능 경영활동 인식의 매개 효과에 대해 검증하고자 한다. 또한 연령별로 친환경 구매의도를 확인하여 화 장품 기업의 마케팅 기초자료로 활용하고자 한다. 따라서 다음과 같은 연구문제를 제시한다.

연구문제1. 소비자의 환경의식 및 친환경 화장품 구매의도와 지속가 능 경영활동의 상관관계를 확인한다.

연구문제2. 화장품 기업의 지속가능 경영활동 인식이 환경의식과 구 매의도와의 매개역할을 하는지 확인한다.

연구문제3. 연령별 차이점을 확인한다. 


\section{Methods}

\section{1. 연구대상 선정 및 자료 수집 기간}

본 연구의 대상자는 화장품을 직접 구입해 본 경험이 있고 화장품을 사용하는 소비자로 20-60대 이상 성인남녀로 선정하였다. 구글 온라 인 설문프로그램을 이용하여 설문조사를 실시하였으며, 설문지는 자기 평가기입식(self administration method)을 사용하여 응답자가 설문내 용을 읽고 답하는 방식이었다. 설문조사는 2021년 2월 21일부터 27일 까지 시행되었다. 371 개의 샘플 데이터에서 결측치(무응답 포함), 정규 성 입증이 어려운 설문문항을 제거한 후 남은 334 개의 데이터로 분석 하였다.

\section{2. 분석방법}

본 연구의 분석방법은 다음과 같다. 자료의 통계분석은 $\mathrm{PASW}$
Statistics by SPSS 18.0 (IBM, USA)을 통하여 분석하였다. 빈도 분석을 통해 응답자의 일반적 특성을 살펴보았으며 설문문항에 대 한 요인분석과 신뢰도분석을 실시하였다. 신뢰성과 타당성 검증은 Cronbach's $\alpha$ 를 사용하였다. 변수 간의 관련성을 확인하고자 상관관 계 분석을 하였다. 회귀분석을 통해 변수 간의 인과관계를 파악하였 고, 매개효과에 대한 통계적 유의성 검증은 Process Macro Model 4, 소벨검증(Sobel, 1982)을 통해 결과를 도출하였다.

\section{3. 설문 구성}

본 연구의 설문은 일반적인 특성 7항목, 소비자의 환경 의식 7항 목, 화장품 기업의 지속가능경영활동 14 항목, 친환경 화장품 구매의 도 4항목, 총 32 개의 문항으로 구성하였다. 각 문항은 5 점 Likert척 도로 구성하였으며, 1점 '전혀 그렇지 않다'와 5점 '매우 그렇다'의 범 주를 사용하였다.

Table 1. General demographic characteristics of the sample

\begin{tabular}{|c|c|c|}
\hline Variable (General characteristics) & Variables & $\mathrm{N}(\%)$ or $\mathrm{M} \pm \mathrm{SD}$ \\
\hline \multirow{2}{*}{ Gender } & Male & $123(36.8)$ \\
\hline & Female & $211(63.2)$ \\
\hline \multirow{5}{*}{ Age } & $20-29$ & $20(15.0)$ \\
\hline & $30-39$ & $133(39.8)$ \\
\hline & $40-49$ & $82(24.6)$ \\
\hline & $50-59$ & $46(13.8)$ \\
\hline & Over 60 & $23(6.9)$ \\
\hline \multirow{4}{*}{ Residence } & Seoul & $138(41.3)$ \\
\hline & Gyeonggi-do/Incheon & $115(34.4)$ \\
\hline & Out of the capital area & $78(23.4)$ \\
\hline & Foreign country & $3(0.9)$ \\
\hline \multirow{2}{*}{ Marriage } & Single & $181(54.2)$ \\
\hline & Married & $4153(5.8)$ \\
\hline \multirow{5}{*}{ Education } & Middle school graduate & $3(0.9)$ \\
\hline & High school graduate & 37 (11.1) \\
\hline & College graduate & $72(21.6)$ \\
\hline & University graduate & $215(64.4)$ \\
\hline & Others & $7(2.1)$ \\
\hline \multirow{4}{*}{ Monthly household income } & Under $90 \mathrm{KRW}$ & $34(10.2)$ \\
\hline & Over 100-299 Under KRW & $145(43.4)$ \\
\hline & Over 300-499 Under KRW & $113(33.9)$ \\
\hline & Over500 KRW & $42(12.6)$ \\
\hline \multirow{6}{*}{ Career in current job } & Company staff & $83(24.9)$ \\
\hline & Public official & $16(4.8)$ \\
\hline & Service occupation & $45(13.5)$ \\
\hline & Businessperson & $38(11.4)$ \\
\hline & Housewife & $21(6.3)$ \\
\hline & Others & $131(39.2)$ \\
\hline
\end{tabular}


일반적 특성으로 성별, 연령 거주지역, 결혼유무, 교육수준, 직업 등으로 구성하였다. 환경의식은 사람들이 환경문제를 인식하는 것과 환경문제를 해결하려는 노력을 지지하며, 개인적으로도 환경 문제를 해결하려는 의지라고 정의할 수 있다(Lin \& Chang, 2012). 본 연구 의 환경의식 측정 도구는 Dunlap et al. (2000)의 신생태적 패러다임 (NEP) 측정항목들 중에서 Lee (2020)가 재 수정하여 사용한 7가지 항목을 사용하였다. 지속가능경영의 개념은 윤리경영에서 파생되었 으며, 1960년대부터 본격적으로 학문적 연구가 시작되었다. 지속가 능경영은 기업의 윤리적 경영과 함께 사회적 책임을 다하는 경영을 강조한 개념으로, 현재 기업의 사회적 책임경영보다 지속가능경영이 라는 용어를 많이 사용하고 있다(Kim, 2006). 화장품 기업의 지속가 능 경영활동 중 친환경 경영 활동을 원료, 제조, 유통, 소비, 폐기의 5단계로 나눈 Park \& Nam (2019)의 연구에서 사용된 14항목의 문 항을 사용하였다. 하위 차원 5 개 요인 중 신뢰도와 타당도 검증을 통 해 신뢰수준이 검증된 유통단계 4 문항 소비단계의 2 문항 총 6 문항 을 분석에 사용하였다. 구매의도는 무언가를 구매하려는 소비자의 의지를 뜻 하며(Rhee \& Ryu, 2012). 친환경 구매의도는 Morrison (1979)의 연구에서 사용한 측정항목들 중(Lee, 2020)가 일부 수정하 여 사용한 4 항목을 본 연구에 맞게 재수정 하여 사용하였다.
본 연구의 대상자인 334 명의 일반적 특성을 살펴보면 다음과 같 다(Table 1). 성별은 남성이 123 명(36.8\%), 여성 211명(63.2\%)으로 여성 비율이 더 높았다. 연령분포는 20 대 50 명(15.0\%), 30대 133 명(39.8\%), 40대 82명(24.6\%), 50대 46명(13.8\%), 60대 이상 23명 (6.9\%)이었으며, 30 대가 133 명으로 가장 큰 비중을 차지했다. 거주 지역은 서울 138 명 $(41.3 \%)$, 경기-인천 115 명 $(34.4 \%)$, 수도권 이 외 78 명 $(23.4 \%)$, 해외 3 명 $(0.9 \%)$ 이다. 결혼상태를 살펴보면 비혼 은 181 명 $(54.2 \%)$, 기혼 153 명(45.8\%)이었다. 교육수준은 중졸 3 명 $(0.9 \%)$, 고졸 37 명(11.1\%), 전문학사 72 명 $(21.6 \%)$, 대졸 이상 215 명(64.4\%), 기타 7명(2.1)으로 대졸 이상이 가장 많았다. 소득수준은 90만 원까지 34명(10.2\%), 100-299만 원 145(43.4\%), 300-499만 원 $113(33.9 \%) 500$ 만 원 이상은 42 명(12.6\%)으로 나타났다.

직업군은 회사원이 83 명(24.9\%), 공무원 16 명(4.8\%), 서비스 직 45명(13.5\%), 자영업 38명(11.4\%), 주부 21명(6.3\%), 기타 131(39.2\%)의 분포를 나타냈다(Table 1).

\section{2. 신뢰도 분석}

문항의 신뢰성은 Cronbach의 $\alpha$ 값을 이용하였으며 분석결과는 다 음과 같다(Table 2). 독립변수인 소비자의 환경의식은 0.754 , 유통 0.704 , 소비 0.633 , 친환경화장품 구매의도는 0.879 이었다. 변수의 신뢰도는 0.600 보다 낮은 문항이 없어 신뢰도가 확보되었다.

\section{3. 요인변수들 간의 상관관계 분석}

연구모형을 검증하기 전에 변수들 간의 상관관계 분석을 실시하였

\section{1. 연구 대상자의 일반적인 특성}

Table 2. Reliability analysis

\begin{tabular}{|c|c|c|c|c|}
\hline Variable & Variable name & Sub-factor & Item & Cronbach's $\alpha$ \\
\hline Independent variable & Environmental concern (EC) & & 7 & 0.754 \\
\hline \multirow{2}{*}{ Mediator variable } & \multirow{2}{*}{ Sustainability management (SM) } & Distribution & 4 & 0.704 \\
\hline & & Consumption & 2 & 0.633 \\
\hline Dependent variable & Purchase intention (PI) & & 4 & 0.879 \\
\hline
\end{tabular}

Table 3. Variable correlation analysis

\begin{tabular}{|c|c|c|c|c|c|c|c|c|c|c|c|c|}
\hline Category & M & SD & 1 & 2 & 3 & 4 & 5 & 6 & 7 & 8 & 9 & 10 \\
\hline Gender & 1.632 & 0.483 & 1 & & & & & & & & & \\
\hline Age & 2.578 & 1.112 & $-0.195^{* *}$ & 1 & & & & & & & & \\
\hline Residence & 1.838 & 0.811 & -0.045 & $0.200^{* *}$ & 1 & & & & & & & \\
\hline Marriage & 1.458 & 0.499 & -0.021 & $0.539^{* *}$ & $0.295^{* *}$ & 1 & & & & & & \\
\hline Education & 3.557 & 0.752 & $0.112^{*}$ & -0.106 & -0.049 & -0.106 & 1 & & & & & \\
\hline $\begin{array}{l}\text { Monthly } \\
\text { household } \\
\text { income }\end{array}$ & 3.500 & 1.445 & $-0.226^{* *}$ & $0.349^{* *}$ & -0.067 & $0.152^{* *}$ & $0.138^{*}$ & 1 & & & & \\
\hline Job & 4.587 & 2.840 & $0.110^{*}$ & 0.032 & $-0.115^{*}$ & 0.041 & 0.056 & -0.080 & 1 & & & \\
\hline EC & 4.403 & 0.534 & 0.065 & $0.123^{*}$ & -0.036 & 0.058 & $0.119^{*}$ & $0.116^{*}$ & 0.037 & 1 & & \\
\hline SM & 4.595 & 0.479 & 0.011 & $0.195^{* *}$ & $0.113^{*}$ & $0.172^{* *}$ & 0.025 & 0.080 & $0.127^{*}$ & $0.433^{* *}$ & 1 & \\
\hline PI & 4.255 & 0.783 & 0.065 & $0.228^{* *}$ & $0.122^{*}$ & $0.161^{* *}$ & 0.018 & $0.154^{* *}$ & $0.110^{*}$ & $0.278^{* *}$ & $0.487^{* *}$ & 1 \\
\hline
\end{tabular}

${ }^{*} p<0.05 ;{ }^{* *} p<0.01$; EC, environmental concern; SM, sustainability management; PI, purchase intention. 
으며 분석결과는 다음과 같다(Table 3). 독립변수인 소비자의 환경의 식은 지속가능경영활동인식 $(\mathrm{r}=0.433, p<0.01)$ 과 친환경화장품구매 의도 $(\mathrm{r}=0.278, p<0.01)$ 에 유의한 상관관계를 보이고 있으며, 통제변 수들과는 거주지역과 부적 관계를 보이고 있고, 성별, 결혼유무, 직 업은 통계적으로 유의미하지 않았다. 또한 매개변수인 지속가능경영 활동 인식은 친환경화장품 구매의도 $(\mathrm{r}=0.487, p<0.01)$ 와 유의한 상 관관계를 보였다. 통제변수들과는 성별, 교육수준, 소득수준은 유의 미하지 않았으며, 나이, 거주지역, 결혼유무, 직업은 정적으로 유의 한 상관관계를 보였다. 종속변수인 친환경화장품 구매의도는 성별, 교육수준은 유의미하지 않았으며, 나이, 거주지역, 결혼유무, 소득수 준, 직업은 유의미한 수준에서 정적관계를 갖고 있다.

\section{4. 소비자의 환경의식 및 친환경 화장품 구매의도와 지속가능 경 영활동의 상관관계}

소비자의 환경의식이 친환경 화장품 구매의도에 영향을 미치는지 알아보기 위해 회귀분석을 실시하였다. 분석결과, $\mathrm{R}$ 제곱은 0.152 , 수정된 R제곱은 $0.131, t$ 값은 4.641, $F$ 값은 7.301, 유의확률 0.000 으로 소비자의 환경의식은 친환경 화장품 구매의도에 영향을 미치는 것으로 나타났다.

소비자의 환경의식은 화장품 기업의 지속가능경영활동 인식에 영 향을 미치는 지에 대한 분석 결과 $\mathrm{R}$ 제곱은 0.236 , 수정된 $\mathrm{R}$ 제곱은 $0.217, t$ 값 $8.444, F$ 값은 12.536 , 유의확률 0.000 으로 소비자의 환
경의식은 화장품 기업의 지속가능경영활동 인식에 영향을 미치는 것 으로 나타났다.

지속가능경영활동인식이 친환경 화장품 구매의도에 영향을 미 치는지 알아보기 위해 회귀분석을 실시하였다. 분석결과 $R$ 제곱은 0.278 , 수정된 R제곱은 $0.261, t$ 값 $9.057, F$ 값은 15.668 , 유의확률 0.000 으로 지속가능경영활동인식이 친환경 화장품 구매의도에 영향 을 유의미한 영향을 미치는 것으로 나타났다(Table 4).

\section{5. 화장품 기업의 지속가능 경영활동 인식이 환경의식과 구매의도 와의 매개역할 검증}

소비자의 환경의식이 화장품 구매의도에 미치는 영향관계에서 기 업의 지속가능 경영활동인식이 매개역할을 하는지 분석하였으며 분 석결과는 다음과 같다(Table 5). 각 경로의 유의성 검증결과 소비 자의 환경의식은 지속가능경영활동 $(\mathrm{B}=0.296, t=8.951, p<0.000)$ 에 영향을 미치고, 소비자 환경의식은 화장품 구매의도 $(\mathrm{B}=0.139$, $t=1.750, p<0.081)$ 에 통계적으로 영향을 미치지 않는 것으로 나 타났다. 기업의 지속가능경영활동이 구매의도 $(\mathrm{B}=0.905, t=7.633$, $p<0.000)$ 에는 유의미한 영향을 미쳤다. 소비자의 환경의식이 화장품 구매의도에 영향을 미치는데 있어 지속가능경영활동인식의 간접효 과 유의성 검증은 bootstrapping을 사용하여 5,000 번 반복 추출하였 다. 분석결과 간접효과의 $95 \%$ 신뢰구간에서 0 을 포함하고 있지 않 기 때문에 정적으로 유의한 것으로 나타났다[CI (0.182-0.376)].

Table 4. Correlation of sustainable management activities with consumers' environmental concern and intention to purchase environmentally friendly cosmetics

\begin{tabular}{|c|c|c|c|c|c|c|c|}
\hline Path & & B & $\mathrm{Se}$ & $\beta$ & $t$ & $p$ & \\
\hline \multirow{2}{*}{$\mathrm{EC} \rightarrow \mathrm{PI}$} & (constant) & 1.647 & 0.411 & \multirow{2}{*}{0.243} & $4.006^{* \star *}$ & 0.000 & \multirow{2}{*}{$\begin{array}{l}R \text { squared }=0.152, \text { modified } R \\
\text { squared }=0.131, F=7.301\end{array}$} \\
\hline & EC & 0.356 & 0.077 & & $4.461^{* * *}$ & 0.000 & \\
\hline \multirow{2}{*}{$\mathrm{EC} \rightarrow \mathrm{SM}$} & (constant) & 2.573 & 0.239 & \multirow{2}{*}{0.419} & $10.776^{* * *}$ & 0.000 & \multirow{2}{*}{$\begin{array}{l}R \text { squared }=0.236, \text { modified } \\
R \text { squared }=0.217, F=12.536\end{array}$} \\
\hline & EC & 0.376 & 0.045 & & $8.444^{* * *}$ & 0.000 & \\
\hline \multirow{2}{*}{$\mathrm{SM} \rightarrow \mathrm{PI}$} & (constant) & 0.101 & 0.418 & \multirow{2}{*}{0.442} & 0.242 & 0.809 & \multirow{2}{*}{$\begin{array}{l}\text { R squared }=0.278, \text { modified } \\
R \text { squared }=0.261, F=15.668\end{array}$} \\
\hline & EC & 0.723 & 0.080 & & $9.057^{* * *}$ & 0.000 & \\
\hline
\end{tabular}

${ }^{* * *} p<0.001$; EC, environmental concern; SM, sustainability management; PI, purchase intention; Se, standard error.

Table 5. Awareness of sustainability management activities from cosmetics companies serves as a medium between environmental concern and purchase intention

\begin{tabular}{lcccc}
\hline Path & B & Se & $t$ & $p$ \\
$\mathrm{EC} \rightarrow \mathrm{SM}$ & 0.296 & 0.033 & $8.951^{* * *}$ & 0.000 \\
$\mathrm{EC} \rightarrow \mathrm{PI}$ & 0.139 & 0.808 & 1.75 & 0.081 \\
$\mathrm{SM} \rightarrow \mathrm{PI}$ & 0.905 & 0.119 & $7.633^{* * *}$ & 0.000 \\
& & Bootstrap results for indirect effect & & \multirow{2}{*}{ BootULCl } \\
Bootstrap & Effect & BootSE & BootLLCl & 0.376 \\
EC & 0.268 & 0.048 & 0.182 & 0 \\
\hline
\end{tabular}

${ }^{* * *} p<0.001$; EC, environmental concern; SM, sustainability management; PI, purchase intention; Se, standard error; BootSE: standard; BootLLCI, BootULCl: statistically significant or significant depending on whether " $O$ " is included in the range. 


\section{3. 연령별 인식 차이 검증}

1) 연령별 환경의식, 지속가능경영활동인식, 친환경 화장품 구매의도 연령별 소비자의 환경의식, 지속가능경영활동인식, 친환경 화장 품 구매의도 인식은 다음과 같다(Table 6). 지속가능경영활동인식과 소비자환경의식, 친환경 화장품구매의도가 연령 별로 차이가 있는지 에 대해 일원배치분산분석(ANOVA)을 하였다. 분석결과는 모든 종 속변수에 대하여 연령 집단 간 유의한 차이가 있었다.

변수별로 살펴보면 소비자 환경의식은 50 대가 4.509 로 가장 높았 고, 20대가 4.197로 가장 낮았다. $F$ 값 2.644 , 유의확률 0.033 으로 유의한 결과가 나왔다. 사후검증결과 20 대, 40 대, 50 대에서 유의한 차이가 있는 것으로 나타났다.

지속가능경영활동인식의 경우, 60 대 이상이 4.754 로 가장 높았 고, 20 대가 4.477 로 가장 낮았다. $F$ 값 3.577 , 유의확률 0.007 로 통 계적으로 유의한 결과가 나왔다. 사후검증결과 30 대, 50 대, 60 대 이 상 간에 유의한 차이가 있는 것으로 나타났다.

친환경화장품 구매의도는 60 대 이상이 4.554 로 가장 높았고, 30 대가 4.047로 가장 낮았다. $F$ 값 6.261 , 유의확률 0.000 로 유의한 결 과가 나왔다. 사후검증결과 전체 연령대에서 유의한 차이가 있는 것 으로 나타났다. 연령에 따라 환경의식, 화장품 기업의 지속가능 경영 인식, 친환경 화장품 구매의도 모두 차이가 있었다.

\section{2) 연령별 지속가능경영활동의 매개효과 분석}

연령별로 소비자의 환경의식이 화장품 구매의도에 미치는 영향관 계에서 기업의 지속가능경영활동인식이 매개역할을 하는지 분석하 였으며 결과는 다음과 같다(Table 7). 간접효과분석결과 20 대-60대
이상 모든 연령대에서 $95 \%$ 신뢰구간에서 0 을 포함하고 있지 않아 간접효과가 있는 것으로 나타났다. 연령대별로 살펴보면 20대(50명) 는 CI(0.047-0.425), 30대(133명)는 CI (0.119-0.436), 40대(82명) 는 CI (0.016-0.368], 50대(46명)는 CI (0.098-0.684), 60대 이상 (23명)은 CI (0.023-0.469)로 나타났다.

\section{Discussion}

코로나 19 의 장기화로 인해 소비자의 환경에 대한 인식이 강화되 면서 화장품기업의 지속가능한 경영활동에 대한 인식도 올라가고 있 다. 따라서 소비자로부터 요구되는 화장품기업의 지속가능경영활동 인식이 친환경 화장품의 구매의도로 이어지는지 확인하고 전략을 모 색하고자 한다. 소비자의 환경의식은 친환경화장품 구매의도와 지속 가능경영활동에 영향을 미치는지 변수들 간에 상관관계를 분석하였 다. 화장품 기업의 지속가능 경영활동 인식이 환경의식과 구매의도 와의 매개역할을 하는지 알아보았다. 마지막으로 연령별 친환경 화 장품 구매의도의 차이점에 대해 분석하였다. 본 연구를 통해 화장품 기업의 지속가능경영활동에 관한 인식제고와 마케팅 성과의 실증 분 석자료로 환경인식 및 화장품기업의 지속가능 경영활동과 친환경 화 장품 구매의도에 관한 구조적 관계를 파악하고자 하였다.

첫째, 소비자의 환경의식은 친환경 화장품 구매의도에 유의미한 영향을 미치는 것으로 나타났다. 이는 환경의식과 DIY화장품을 연구 한 Kim \& Yoo (2016)의 연구와 중국 소비자를 대상으로 친환경 제 품에 대한 연구를 진행한 Lee (2020)의 연구결과 와도 일치한다. 또

Table 6 Environmental concern, awareness of sustainability management activities, and purchase intention of environmentally friendly cosmetics per age

\begin{tabular}{|c|c|c|c|c|c|c|c|}
\hline Variable & Age & Frequency $(\mathrm{N})$ & M & SD & $F$ & $p$ & Comparison \\
\hline \multirow{5}{*}{ EC } & $20-29$ & 50 & 4.197 & 0.552 & 2.644 & $0.0334^{*}$ & \multirow{5}{*}{$\begin{array}{l}\text { a<c, d } \\
\text { Tukey }\end{array}$} \\
\hline & $30-39$ & 133 & 4.408 & 0.542 & & & \\
\hline & $40-49$ & 82 & 4.465 & 0.537 & & & \\
\hline & $50-59$ & 46 & 4.509 & 0.469 & & & \\
\hline & Over 60 & 23 & 4.391 & 0.486 & & & \\
\hline \multirow{5}{*}{ SM } & $20-29$ & 50 & 4.477 & 0.531 & 3.577 & $0.007^{\star *}$ & \multirow{5}{*}{$\begin{array}{c}\mathrm{b}<\mathrm{d}, \mathrm{e} \\
\text { Games-Howell }\end{array}$} \\
\hline & $30-39$ & 133 & 4.521 & 0.530 & & & \\
\hline & $40-49$ & 82 & 4.673 & 0.421 & & & \\
\hline & $50-59$ & 46 & 4.717 & 0.360 & & & \\
\hline & Over 60 & 23 & 4.754 & 0.317 & & & \\
\hline \multirow{5}{*}{$\mathrm{PI}$} & $20-29$ & 50 & 4.135 & 0.763 & 6.261 & $0.000^{* * *}$ & \multirow{5}{*}{$\begin{array}{c}\mathrm{a}<\mathrm{e} \\
\mathrm{b}<\mathrm{c}, \mathrm{d}, \mathrm{e} \\
\text { Games-Howell }\end{array}$} \\
\hline & $30-39$ & 133 & 4.047 & 0.889 & & & \\
\hline & $40-49$ & 82 & 4.430 & 0.665 & & & \\
\hline & $50-59$ & 46 & 4.527 & 0.620 & & & \\
\hline & Over 60 & 23 & 4.554 & 0.426 & & & \\
\hline
\end{tabular}

EC, environmental concern; SM, sustainability management; PI, purchase intention; ${ }^{*} p<0.05 ;{ }^{* *} p<0.01 ;{ }^{* * *} p<0.001$. 
한 대학생을 대상으로 연구한 Han \& Lee (2016)과 Kang \& Song (2019)의 연구에서도 환경보호에 대한 의식이 높은 학생들이 친환경 제품 및 친환경화장품에 대한 구매의도에 통계적으로 유의한 영향을 미쳤다는 결과 와도 일치한다. 하지만 환경의식을 환경에 대한 관심 과 지식으로 나누어 변수로 이용한 Ryu et al. (2017)과 Kim et al. (2018)의 연구에서는 환경에 대한 관심은 친환경 제품 구매의도에 영향을 미치지 못하는 것으로 나타났다. 반면 소비자의 환경지식은 친환경 제품 구매의도에 유의한 영향을 주는 것으로 나타났다. 이는 환경에 대해 관심이 있다고 해서 친환경 제품에 대한 구매의도를 가 지지는 않지만 환경지식이 구매의도로 연결되고 실제 구매행동에 정 의 영향을 미치는 것으로 나타났다. Chun et al. (2018)의 연구에서
는 환경친화적 신념이 제품태도, 업사이클링 패션 브랜드태도에 긍 정적인 영향을 미치는 것으로 나타났지만 구매의도에는 영향을 미치 지 않은 것으로 본 연구결과와는 상이하게 나타났다.

소비자의 환경의식은 화장품 기업의 지속가능경영활동 인식에 영 향을 미치는 지에 대한 분석 결과 소비자의 환경의식은 화장품 기업 의 지속가능경영활동 인식에 유의미한 영향을 미치는 것으로 나타났 다. 이는 Park \& Nam (2019)의 연구에서 환경가치관이 높은 사람 들은 기업의 지속가능활동을 중요하게 생각하는 것으로 나타난 것과 일치한다. 중소기업의 환경경영에 영향을 미치는 요인을 연구한 $\mathrm{Oh}$ $\& \operatorname{Kim}$ (2014)의 연구에서는 환경의식 확산이 내부시스템 개편에 영 향을 미치고, 내부 시스템 개편은 외부네트워크 활용에 긍정적 영향

Table 7. Analysis of mediating effects of sustainability management activities by age

\begin{tabular}{|c|c|c|c|c|c|}
\hline Age & Path & $\mathrm{B}$ & Se & $t$ & $p$ \\
\hline \multirow{6}{*}{$20-29(50)$} & $\mathrm{EC} \rightarrow \mathrm{SM}$ & 0.269 & 0.105 & 2.551 & 0.014 \\
\hline & $\mathrm{EC} \rightarrow \mathrm{PI}$ & 0.017 & 0.194 & 0.089 & 0.929 \\
\hline & $\mathrm{SM} \rightarrow \mathrm{PI}$ & 0.761 & 0.249 & $3.057^{* *}$ & 0.004 \\
\hline & \multicolumn{5}{|c|}{ Bootstrap results for indirect effect } \\
\hline & Bootstrap & Effect & BootSE & BootLLCl & BootULCI \\
\hline & SM & 0.205 & 0.097 & 0.047 & 0.425 \\
\hline \multirow{6}{*}{ 30-39 (133) } & $\mathrm{EC} \rightarrow \mathrm{SM}$ & 0.280 & 0.056 & $5.003^{* * *}$ & 0.000 \\
\hline & $\mathrm{EC} \rightarrow \mathrm{PI}$ & 0.169 & 0.141 & 1.196 & 0.234 \\
\hline & $\mathrm{SM} \rightarrow \mathrm{PI}$ & 0.906 & 0.202 & $4.487^{* * *}$ & 0.000 \\
\hline & \multicolumn{5}{|c|}{ Bootstrap results for indirect effect } \\
\hline & Bootstrap & Effect & BootSE & BootLLCI & BootULCl \\
\hline & SM & 0.254 & 0.082 & 0.119 & 0.436 \\
\hline \multirow{6}{*}{$40-49(82)$} & $\mathrm{EC} \rightarrow \mathrm{SM}$ & 0.293 & 0.056 & $5.210^{* * *}$ & 0.000 \\
\hline & $\mathrm{EC} \rightarrow \mathrm{PI}$ & 0.242 & 0.145 & 1.666 & 0.100 \\
\hline & $\mathrm{SM} \rightarrow \mathrm{PI}$ & 0.641 & 0.249 & $2.570^{*}$ & 0.012 \\
\hline & \multicolumn{5}{|c|}{ Bootstrap results for indirect effect } \\
\hline & Bootstrap & Effect & BootSE & BootLLCl & BootULCI \\
\hline & SM & 0.188 & 0.089 & 0.016 & 0.368 \\
\hline \multirow{6}{*}{$50-59(46)$} & $\mathrm{EC} \rightarrow \mathrm{SM}$ & 0.357 & 0.084 & $4.239^{* * *}$ & 0.000 \\
\hline & $\mathrm{EC} \rightarrow \mathrm{PI}$ & 0.008 & 0.200 & 0.041 & 0.967 \\
\hline & $\mathrm{SM} \rightarrow \mathrm{PI}$ & 1.080 & 0.302 & $3.571^{* *}$ & 0.001 \\
\hline & \multicolumn{5}{|c|}{ Bootstrap results for indirect effect } \\
\hline & Bootstrap & Effect & BootSE & BootLLCI & BootULCI \\
\hline & SM & 0.385 & 0.149 & 0.098 & 0.684 \\
\hline \multirow{6}{*}{ Over $60(23)$} & $\mathrm{EC} \rightarrow \mathrm{SM}$ & 0.265 & 0.086 & $3.065^{* *}$ & 0.006 \\
\hline & $\mathrm{EC} \rightarrow \mathrm{PI}$ & 0.116 & 0.194 & 0.600 & 0.555 \\
\hline & $\mathrm{SM} \rightarrow \mathrm{PI}$ & 0.894 & 0.408 & $2.193^{*}$ & 0.040 \\
\hline & \multicolumn{5}{|c|}{ Bootstrap results for indirect effect } \\
\hline & Bootstrap & Effect & BootSE & BootLLCl & BootULCI \\
\hline & SM & 0.237 & 0.110 & 0.023 & 0.469 \\
\hline
\end{tabular}

EC, environmental concern; SM, sustainability management; PI, purchase intention; BootSE: standard; BootLLCl, BootULCl: statistically significant or significant depending on whether " 0 " is included in the range; " $p<0.05 ;{ }^{* *} p<0.01 ;{ }^{* * *} p<0.001$. 
을 미치는 것 과도 유의한 결과이다.

지속가능경영활동 인식은 친환경화장품 구매의도에 유의미한 영 향을 미치는 것으로 나타났다. 이는 Nam-Koong \& Kim (2018)과 Oh (2020)의 연구에서도 친환경 경영 속성이 친환경 화장품 구매의 도에 유의한 영향을 미치는 것으로 나타나 본 연구 결과를 지지해준 다. Yoon \& Jung (2018)의 연구에서도 친환경 지속가능경영 전략을 추구하는 다국적 기업의 제품과 서비스는 '신뢰'와 '구매의도'에 대부 분 긍정적인 영향을 미치는 것으로 나타났다. Lee \& Kim (2015)도 지각된 SPA 브랜드의 지속가능경영 활동으로 형성된 브랜드 태도, 소비자 만족이 구매의도에 유의한 영향을 미친다고 하였다. Yoon \& Jung (2020)의 연구에서는 연구의 실증분석 결과, 지속가능경영 전 략의 환경적 전략은 기업이미지에 긍정적인 영향을 주는 것으로 나 타났다. 하지만 구매의도에 직접적인 영향은 없는 것으로 나타나 본 연구와는 상이한 결과이다. Oh (2020)와 Yoon \& Jung (2020)의 연 구에서 기업의 친환경 경영 요인이 기업이미지에 영향을 주고 구매 의도에 미치는 관계에 있어서, 긍정적인 효과를 주었다.

둘째, 소비자의 환경의식이 화장품 구매의도에 미치는 영향관계 에서 기업의 지속가능 경영활동인식이 매개효과가 유의한 것으로 확 인되었다. 각 경로의 유의성 검증결과 소비자의 환경의식은 지속가 능경영활동에 영향을 미치고, 소비자 환경의식은 화장품 구매의도에 통계적으로 영향을 미치지 않는 것으로 나타났다. 기업의 지속가능 경영활동이 구매의도에는 유의미한 영향을 미쳤다. 소비자의 환경의 식이 화장품 구매의도에 영향을 미치는데 있어 지속가능경영활동인 식의 간접효과는 유의한 것으로 나타났다. 이는 Park \& Nam (2019) 의 연구 결과와 일치한다.

마지막으로 소비자의 환경의식, 지속가능경영활동 인식과 친환경 화장품 구매의도는 연령별로 유의한 차이가 있었다. 소비자 환경의 식은 50대, 40대, 30 대, 60 대 이상, 20 대 순으로 나타났다. Bao et al. (2019)의 연구에서 20대, 30대에 비해 연령이 높을수록 더 긍정 적인 친환경태도 및 환경정체성을 가지는 것으로 나타났다. 60 대 이 상의 결과가 본 연구와 차이가 있다. 하지만 본 연구에서 60 대 이상 의 샘플 수가 적어서 일반화하기 어려운 점이 있는 점을 반영하면 이 는 유의한 결과라고 할 수 있다.

지속가능경영활동인식의 경우, 60 대 이상, 50 대, 40,30 대, 20 대 순으로 높았다. 연령이 많을 수록 환경에 대한 인식이 높게 측정되었 다. 사후검증결과 20 대, 40 대, 50 대에서 유의한 차이가 있는 것으로 나타났다. 친환경 태도에 따른 의복선택을 연구한 Park (2016)의 연 구에서 기업의 친환경에 대한 관심에서 연령별로 유의한 차이를 보 이지 않아 본 연구와는 차이가 있다.

친환경화장품 구매의도는 60 대 이상, 50 대, 40 대, 20 대, 30 대 순 으로 나타났다. 사후검증결과 전체 연령대에서 유의한 차이가 있는 것으로 나타났다. 이는 Bao et al. (2019)의 연구와 일치하며, Park (2016)의 연구에서도 의복 구매 시 연령대가 높아질수록 친환경성은 더 중요한 의복선택기준으로 작용한다는 것을 알 수 있어 본 연구를
지지해 준다.

연령별 소비자의 환경의식이 화장품 구매의도에 미치는 영향관계 에서 기업의 지속가능경영활동인식이 간접효과 분석결과 20 대 -60 대 이상 모든 연령대에서 간접효과가 있는 것으로 나타났다.

전체적으로 연령대가 높을수록 환경에 대한 의식과 화장품 기업의 지속가능 경영활동 및 구매의도가 모두 높게 나타났다. Bao et al. (2019)은 연령이 높아질 수 록 자기 생활 경험이 많아지고 자신에 대 한 인식이 더 선명해져 보다 적극적으로 실제 행동으로 실천하는 것 으로 볼 수 있다고 하였다. 특히 50 대, 60 대 대부분이 자녀나 자손이 있으므로, 후대에 대해서 더 많이 생각하고 고려하여 적극적으로 친 환경 소비행동을 실천하는 것으로 추측할 수 있다(Park, 2016). 따 라서 친환경 화장품을 기획할 때는 연령별로는 젊은층 보다는 40 대 및 50 대의 중장년층 소비자들에게 친환경적인 가치를 어필하는 것 이 더 효과적일 것으로 사료된다.

소비자들이 좀 더 친환경을 추구하는 제품의 가치를 인식하게 되 었고 의식 있는 소비를 하고자 변화되고 있다. 그러나 코로나19 이 후 '재활용' 관련 범주가 아직까지는 나타나지 않았다. 이는 직·간접 적인 접촉으로 인한 전염을 피하고자 불가피하게 일회용품 사용이 증가된 것과 같이 언택트 문화의 확산에 따른 공유, 재활용에 대한 불안감이 소비자 의식에 영향을 미친 것이 아닌가 생각된다(Koh \& Lee, 2020).

최근 코로나19로 인해 환경에 대한 우려가 높아졌다고도 볼 수 있 으나, 환경의식과 친환경 화장품의 구매의도와 관계를 살펴보는 실 증적 연구는 아직까지 초기 단계이다. 또한 포스트 코로나 시대의 인 식 변화에 대해서는 아직은 판단하기 어렵다. 따라서 향후 환경의식 이나 친환경 지속가능경영 인식, 친환경 화장품의 구매의도에 관한 연구는 지속적인 연구가 필요할 것이라고 생각된다. 특히 연령에 따 른 후속 연구가 진행된다면 세분화된 마케팅을 진행하는데 좀 더 의 미 있을 것이라고 사료된다.

\section{Conclusion}

본 연구는 포스트코로나 시대의 소비자의 환경의식과 화장품기업 의 지속가능경영 인식 및 친환경화장품 구매의도에 관해 검증하였다 소비자의 환경의식은 친환경 화장품 구매의도에 유의미한 영향을 미치는 것으로 나타났다. 소비자의 환경의식은 화장품 기업의 지속 가능경영활동 인식에 영향을 미치는 지에 대한 분석 결과 소비자의 환경의식은 화장품 기업의 지속가능경영활동 인식에 유의미한 영향 을 미치는 것으로 나타났다. 지속가능경영활동 인식은 친환경화장품 구매의도에 유의미한 영향을 미치는 것으로 나타났다.

소비자의 환경의식이 화장품 구매의도에 미치는 영향관계에서 기 업의 지속가능 경영활동인식이 매개효과가 유의한 것으로 확인되었 다. 각 경로의 유의성 검증결과 소비자의 환경의식은 지속가능경영 
활동에 영향을 미치고, 소비자 환경의식은 화장품 구매의도에 통계 적으로 영향을 미치지 않는 것으로 나타났다. 기업의 지속가능경영 활동 인식이 구매의도에는 유의미한 영향을 미쳤다. 소비자의 환경 의식이 화장품 구매의도에 영향을 미치는데 있어 지속가능경영활동 인식의 간접효과는 유의한 것으로 나타났다.

소비자의 환경의식, 지속가능경영활동 인식과 친환경화장품 구매 의도는 연령별로 유의한 차이가 있었다. 소비자 환경의식은 50 대, 40 대, 30 대, 60 대 이상, 20 대 순으로 나타났다. 지속가능경영활동 인식의 경우, 60 대 이상, 50 대, 40,30 대, 20 대 순으로 높았다. 연 령이 높을 수록 환경에 대한 인식이 높게 측정되었다. 사후검증결과 20 대, 40 대, 50 대에서 유의한 차이가 있는 것으로 나타났다. 친환경 화장품 구매의도는 60 대 이상, 50 대, 40 대, 20 대, 30 대 순으로 나타 났다. 사후검증결과 전체 연령대에서 유의한 차이가 있는 것으로 나 타났다. 연령별 소비자의 환경의식이 화장품 구매의도에 미치는 영 향관계에서 기업의 지속가능경영활동인식이 간접효과 분석결과 20 대-60대 이상 모든 연령대에서 간접효과가 있는 것으로 나타났다. 전체적으로 연령대가 높을수록 환경에 대한 의식과 화장품 기업의 지속가능 경영활동 및 구매의도가 모두 높게 나타났다.

코로나19 발생 이후 전 세계적으로 환경의식이 높아지고 있는 것 은 자명하다. 이는 기업의 경영활동에도 영향을 주고 있다. 소비자 의 요구로 음료에 부착되어 있는 플라스틱 빨대나 통조림 햄의 뚜껑 등이 사라져 가고 있으며 이런 변화는 확장되는 추세이다. 수익에 초 점을 두고 진행했던 사업들이 점차 가치소비, 환경 등에 초점을 두 어 판매자와 소비자 모두의 마음을 사로잡고 있다. 기업입장에서는 환경보호만이 아니라 원가 절감과 소비자의 구매의도에 영향을 주어 매출의 증가로 이어지기도 한다.

포스트코로나 시대에는 변화되는 소비자의 인식에 따라 화장품 기 업 또한 소비자의 인식에 따른 지속가능경영에 관한 마케팅 전략이 필요 할 것으로 사료된다.

본연구가 지니는 몇 가지 한계점과 함께 향후 연구에 대한 가능성 을 제시하면 다음과 같다. 첫째, 본 연구에서 화장품 기업의 지속가 능경영에 대해 소비자의 친환경 화장품 구매의도에 대해 살펴보았 다. 설문조사 진행 시 지속가능소비에 대한 설명에 제시 했음에도 불 구하고 소비자 입장에서 지속가능경영에 대한 이해가 완벽하게 이루 어졌다고 보기 어렵다. 둘째, 대부분의 소비자의 친환경 화장품 구 매의도가 높게 나왔지만 실제 구매행동으로 이어지는지에 대해서는 알 수 없다. 친환경 화장품의 구매의도와 구매행동 간의 관계를 살펴 보는 실증적 연구는 아직까지 초기 단계이다. 앞으로 구매의도뿐 아 니라 구매 행동까지 살펴볼 수 있는 연구가 늘어난다면 더 의미가 있 을 것으로 본다. 셋째, 국내 소비자를 대상으로 연구를 하여 내수시 장의 마케팅에 대한 자료를 제공하였지만 글로벌 경영을 하는 기업 의 해외 소비자의 인식에 대한 연구가 이루어 지지 못했다. 마지막으 로, 친환경 화장품에 대한 구매의도가 높게 나왔지만, 화장품 기업이 소비자에게 어떤 방법으로 친환경 화장품을 홍보해야 하는지에 대한
연구는 진행되지 않았다. 따라서 지속가능경영활동을 어떤 방법으로 진행하고 친환경 화장품을 소비자에게 적극 인식시킬 수 있는지 후 속 연구가 필요할 것이라 사료된다.

\section{Author's contribution}

MHK reviewed literature, analyzed the data, and wrote the manuscript, SJP reviewed literature and performed questionnaires.

\section{Author details}

Min-Hye Kim (Graduate student), Department of Cosmetics Engineering, Konkuk University, 120 Neungdong-ro, Gwangjin-gu, Seoul 05029 Korea; Seunghee Bae (Professor) Research Institute for MolecularTargeted Drugs, Department of Cosmetics Engineering, Konkuk University, 120 Neungdong-ro, Gwangjin-gu, Seoul 05029 Korea.

\section{References}

Bao XM, Park JC, Joung SH. Determinants of eco-friendly consumption behavior: focusing on eco-friendly attitude, environmental identity and normalization of eco-friendly consumption behaviors. Consumer Policy and Education Review, 15: 127-149, 2019.

Cho $\mathrm{CH}$, Han MS. A study on the effect of corporate social responsibility recognition on the measurement \& disclosure of environmental preservation expenses and sustainable management. Global Business Administration Review, 14: 67-97, 2017.

Chun EH, Jiang W, Yu J, Ko E. Perceived consumption value, pro-environmental belief, attitude, eWOM, and purchase intention toward upcycling fashion products. Fashion \& Textile Research Journal, 20: 177-190, 2018.

Dunlap RE, Van Liere KD, Mertig AG. New trends in measuring environmental attitudes: measuring endorsement of the new ecological paradigm: a revised NEP scale. Journal of Social Issues, 56: 425-442, 2000.

Han DY, Lee Jl. An effect of the eco-friendly consciousness of the undergraduate by the lifestyle on the purchase intention of the eco-friendly products. Journal of Digital Convergence, 14: 83-91, 2016.

Jeung GC. A study on the CSR management approaches 
of beauty industry in Korea. Journal of Beauty Art Management, 14: 59-76, 2020.

Kang GH, Jeong WD. The effects of corporate efforts for the sustainable management on the corporate trust and purchase intention. Kyung Young Nonchong,35: 1-14, 2014.

Kang MJ, Song YJ. University students' awareness and purchasing behavior on up-cycling beauty products. Korean Society of Cosmetics and Cosmetology, 9: 417427, 2019.

Kim DY. A study of marketing strategy of food service business for sustainable development management: focused on service quality control of family food restaurant. Journal of Mice \& Tourism Research, 12: 121-144, 2006.

Kim SR, Yoo TS. An analysis of structural relations among perception of DIY cosmetics, environmental awareness, good life-style and consuming behavior practice of consumers. Journal Korea Society of Visual Design Forum, 51: 125-136, 2016.

Kim SW, Lee SH, Moon SJ. Influence of consumer's environmental consciousness on purchasing behavior of eco-friendly products. Journal of Marketing Studies, 26: 56-72, 2018.

Kim SY. A case study on the CSR activities in the cosmetic industry for sustainable management. Journal of Sustainability Research, 3: 73-89, 2012.

Koh AR, Lee JS. Sustainable fashion consumption in the postCOVID-19 era. Journal of Consumer Studies, 31: 1-17, 2020.

Kong Y, Hong S. Effects of corporate social responsibility (CSR) on perceived quality and customer satisfaction: focused on the implications of post-corona era. The Journal of Humanities and Social science, 11: 1-16, 2020.

Lee HT, Park YG, Park JJ. The effect of sustainability drivers on sustainability management activities and performance: the moderating effect of innovation types. Journal of Business Research, 35: 35-53, 2020.

Lee J, Kim S. The influence of sustainability management fit of SPA brand on consumer purchase intention. The Research Journal of the Costume Culture, 23: 161-175, 2015.

Lee JM, An SK, Jang HH. Effects of Hippohae rhamnoides extracts on skin conditions. Asian Journal of Beauty and Cosmetology, 19: 35-46, 2021.

Lee KS, Lee HS. Influence of the cosmetic company's eco- friendly activities on brand equity. Journal of Beauty Art Management, 6: 267-274, 2012.

Lee YK. Impacts of environmental concern, materialism and empathy on pro-environmental consumption behavior: evidence from China. International Area Studies Review, 24: 155-175, 2020.

Lin YC, Chang CCA. Double standard: the role of green product usage. Journal of Marketing, 76: 125-134, 2012.

Morrison DG. Purchase intentions and purchase behavior, Journal of Marketing, 43: 65-74, 1979.

Nam-Koong Y, Kim EJ. The effect of eco-friendly management activities of a cosmetic company on customers'decision making. Journal of the Korea Convergence Society, 9: 285-291, 2018.

Oh JH, Kim JD. A study on external factors and appropriate activities for SMEs' environmental management. Asia Pacific Journal of Small Business, 36: 159-187, 2014.

Oh YJ. Influence of a cosmetic company's eco-friendly activities on consumers' purchase intention through the mediating effects of perceived image. Asian Journal of Beauty and Cosmetology, 18: 149-161, 2020.

Park HJ, Nam MW. Consumer's perception of corporate's sustainability and the environmental friendly cosmetics consumption behavior. The Korean Society of Science \& Art, 37: 157-172, 2019.

Park $\mathrm{YH}$. The clothing selection criteria according to consumers eco-friendly attitude and demographic characteristics. Journal of the Korea Fashion \& Costume Design Association, 18: 11-22, 2016.

Park YM, Kim HY. A study on changes in women's makeup Interest and use patterns before and after the outbreak of COVID-19. Asian Journal of Beauty and Cosmetology, 19: 129-138, 2021.

Rhee HJ, Ryu SH. Effects of social values of social enterprises on attitude towards social enterprises and purchase intention: mediating effects of identification. Academy of Customer Satisfaction Management, 14: 197-216, 2012.

Ryu ES, Suh SW, Kim YG. The effect of environmental knowledge and environmental concern on the purchase intention of eco-friendly wine: focusing on the moderating role of customer involvement. Journal of Tourism Sciences, 41: 183-200, 2017.

Sobel ME. Asymptotic confidence intervals for indirect effects in structural equation models. Sociological Methodology, 
13: 290-312, 1982.

Yoon YH, Jung JS. The impact of multinational enterprises' sustainability management strategy on purchase Intention of products: focusing on the mediating effect of corporate image. Journal of Strategic Management, 23: 49-79, 2020.
Yoon YH, Jung JS. The impact of consumer perception on purchasing intention on the sustainable management of multinational enterprise: focused on mediating effects of trust. International Business Journal, 29: 85-121, 2018. 


\section{국문초록}

\section{포스트 코로나시대의 소비자의 환경의식이 화장품 기업의 지속가능경영 활동 인식을 매개로 친환경 화장품 구매의도에 미치는 영향}

김민혜 ${ }^{1}$, 배승희 ${ }^{2 *}$

${ }^{1}$ 건국대학교 화장품공학과, 서울, 한국

${ }^{2}$ 건국대학교 화장품공학과 질병분자표적신약연구소, 서울, 한국

목적: 본 연구에서는 포스트 코로나 시대의 소비자들의 환경의식이 화장품 기업의 지속가능경영 활동 인식과 친환경 화장품 구매의 도에 영향을 주는 구조적 관계를 파악하고자 한다. 방법: 설문조사는 2021년 2월 21-27일 화장품을 사용하는 성인을 대상으로 시 행되었다. 371개의 샘플 중 유효한 334개의 데이터로 분석하였다. 본 연구의 자료는 SPSS 18.0 프로그램을 사용하여 빈도분석을 하였고, Cronbach's $\alpha$ 를 통해 신뢰성과 타당성을 검증하였다. 결과: 소비자의 환경의식은 친환경 화장품 구매의도와 화장품 기업의 지속가능경영활동 인식에 유의미한 영향을 미치는 것으로 나타났다. 지속가능경영활동 인식은 친환경화장품 구매의도에 유의미한 영향을 미치는 것으로 나타났다. 소비자의 환경의식이 화장품 구매의도에 미치는 영향관계에서 기업의 지속가능 경영활동인식이 매개효과가 유의한 것으로 확인되었다. 전체적으로 연령대가 높을수록 환경에 대한 의식과 화장품 기업의 지속가능 경영활동 인식 및 구매의도가 모두 높게 나타났다. 기업의 지속가능경영활동 인식의 간접효과 분석결과 20대-60대 이상 모든 연령대에서 간접효 과가 있는 것으로 나타났다. 결론: 포스트 코로나 시대의 소비자의 환경의식이 화장품 기업의 지속가능경영활동 인식과 친환경화장 품 구입에 영향을 주었다. 이를 대비하여 화장품 기업은 기업과 소비자가 모두 만족할 수 있는 지속가능경영 전략을 모색하고 실천 해야 한다.

핵심어: 포스트 코로나, 환경의식, 지속가능경영, 친환경 화장품, 구매의도

\section{참고문헌}

강명주, 송연재. 업사이클링 화장품에 대한 대학생 소비자의 태도 및 구매행동. 한국화장품미용학회지, 9: 417-427, 2019.

강지호, 정원덕. 지속가능 경영이 기업신뢰 및 구매의도에 미치는 영향. 경영논총, $35: 1-14,2014$.

고애란, 이정순. 포스트 코로나 시대의 지속가능 패션 소비. 소비자학연구, 31: 1-17, 2020.

공윤엽, 홍성준. 기업의 사회적 책임이 지각된 품질 및 고객만족에 미치는 영향: 포스트코로나 시대 함의를 중심으로. 인문 사회 $21,11: 1-16,2020$.

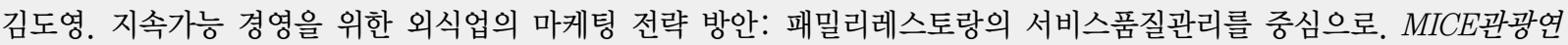

구, 12: 121-144, 2006.

김사원, 이수형, 문선정. 소비자의 환경의식이 친환경 제품 구매행동에 미치는 영향. 마케팅논집, 26: 56-72, 2018.

김선령, 유태순. 소비자의 DIY 화장품 인식, 환경의식, 착한 라이프스타일, 소비실천행동 간의 구조적 관계. 한국디자인포

럼, 51: 125-136, 2016.

김성윤. 지속가능한 경영을 위한 글로벌 화장품 기업의 CSR(Corporate Social Responsibility) 사례연구. 지속가능연구,

3: 73-89, 2012.

남궁윤, 양은진. 미용기업의 친환경 경영활동이 소비자 의사결정에 미치는 영향. 한국융합학회논문지, 9: 285-291, 2018

류을순, 서상원, 김유경. 환경지식과 환경관심이 친환경 와인 구매의도에 미치는 영향: 관여도의 조절효과와 함께. 관광학 
연구, 41: 183-200, 2017.

박영희. 소비자의 친환경 태도 및 인구통계적 특성에 따른 의복선택 기준의 특징. 한국의상디자인학회지, $18: 11-22$, 2016.

박윤미, 김휘율. 코로나 19 (COVID-19) 발생 이전·이후의 여성 화장 관심도 및 화장품 사용실태 변화 분석. 아시안뷰티화

장품학술지, 19: 129-138, 2021.

박현정, 남미우. 기업의 지속가능 경영활동에 대한 소비자 인식과 친환경 화장품 소비행동. 한국과학예술융합학회, 37 :

157-172, 2019.

오유진. 화장품 기업의 친환경활동이 지각된 이미지를 매개로 화장품 구매의도에 미치는 영향. 아시안뷰티화장품학술지,

18: $149-161,2020$.

오주환, 김지대. 중소기업의 환경경영에 영향을 끼치는 외부요인과 적합한 활동에 관한 연구. 중소기업연구, $36: 159-$ 187, 2014.

윤영호, 정진섭. 다국적 기업의 지속가능경영 전략이 제품의 구매의도에 미치는 영향: 기업이미지의 매개효과 중심으로.

전략경영연구, 23: 49-79, 2020

윤영호, 정진섭. 다국적 기업의 지속가능경영에 대한 소비자 인식이 구매의도에 미치는 영향: 신뢰의 매개효과 중심으로.

국제경영연구, 29: 85-121, 2018.

이경숙, 이현숙. 화장품 기업의 친환경 활동이 브랜드 자산에 미치는 영향. 미용예술경영연구, $6: 267-274,2012$.

이유경. 중국 소비자의 환경의식, 물질주의, 공감이 친환경 소비행동에 미치는 영향. 국제지역연구, $24: 155-175,2020$.

이정민, 안성관, 장현희. 비타민나무 추출물이 피부상태에 미치는 영향. 비타민나무 추출물이 피부상태에 미치는 영향. 아

시안뷰티화장품학술지, 19: 35-46, 2021

이지민, 김선희. SPA 브랜드의 지속가능경영 활동 적합성이 구매의도에 미치는 영향. 복식문화연구, $23: 161-175$, 2015.

이호태, 박영근, 박재진. 지속가능동인이 지속가능경영활동과 기업성과에 미치는 영향. 경영연구, $35: 35-53,2020$.

이형재, 류선호. 사회적 가치가 사회적 기업에 대한 태도와 구매의도에 미치는 영향: 동일시의 효과. 고객만족경영연구,

14: 197-216, 2012.

전은하, 강미, 유지혜, 고은주. 업사이클링 패션제품에 대한 지각된 소비가치, 환경친화적 신념, 태도, 온라인 구전의도 및

구매의도에 관한 연구. 한국의류산업학회지, 20: 177-190, 2018.

정길채. 우리나라 뷰티 산업 기업의 사회적 책임경영 개선 방안에 관한 연구. 미용예술경영연구, 14: 59-76, 2020.

조철호, 한문성. 기업의 사회적 책임 인식이 환경보전비용의 측정 및 공시와 지속가능경영에 미치는 영향에 관한 연구. 글 로벌경영학회지, 14: 67-97, 2017.

포하매, 박진채, 정순희. 친환경 소비행동 실천에 영향을 미치는 요인에 관한 연구: 친환경태도, 환경정체성 및 친환경 소 비행동의 사회적 일반화인식을 중심으로. 소비자정책교육연구, 15: 127-149, 2019.

한동여, 이정임. 라이프스타일 유형에 따른 대학생의 환경의식이 친환경제품의 구매의도에 미치는 영향. 디지털융복합연

구, 14: 83-91, 2016. 


\section{中文摘要}

\section{后新冠时代以化妆品公司的可持续性管理活动意识为媒介消费者环境关注对环 保化妆品购买意愿的影响}

金珉惠 ${ }^{1}$, 裴承熙 $^{2 *}$

建国大学化妆品学科, 首尔, 韩国

2建国大学化妆品学科疾病分子靶标新药研究所，首尔，韩国

目的：本研究探讨后新冠时代消费者对环境的关注与其对环保化妆品的购买意愿和化妆品公司实施的可持续性 管理活动的看法之间的结构相关性。方法：2021年2月21日至 27日，对使用化妆品的成年人进行问卷调查。从 371份样本中最终334份有效样本进行数据分析。数据分析采用SPSS 18.0软件进行频数分析, 信度和效度通过 Cronbach's a检验。结果: 发现消费者对环境的关注对购买环保化妆品的意愿和化妆品公司实施的可持续性管理 活动的意识有显着影响。相反, 可持续性管理活动的意识显着影响了环保化妆品的购买意愿。还发现可持续性 管理活动的感知通过影响化妆品购买意愿在消费者环境关注中发挥了巨大的中介作用。总体而言，环境关注、 公司实施的可持续发展管理活动的意识和购买意愿随着団队年龄的增长而增长。分析表明, 企业可持续发展管 理活动的意识对 20 至 60 岁的所有年龄组都有间接影响。结论: 后新冠时代消费者对环境的担忧影响了化妆品 公司对可持续性管理活动的认识，同时影响了环保化妆品的购买。根据这种意识，化妆品公司应寻求实施使公 司和消费者都满意的可持续发展管理战略。

关键词: 后新冠，环境关注，可持续发展管理，环保化妆品，购买意向 